\title{
Implementasi Algoritma Greedy Pada Pewarnaan Wilayah Kecamatan Sukodadi Lamongan
}

\author{
Umi Maftukhah $^{1}$, Siti Amiroch ${ }^{2}$, Mohammad Syaiful Pradana $^{3}$ \\ ${ }^{1}$ Universitas Islam Darul Ulum Lamongan, maftukha367@gmail.com \\ ${ }^{2}$ Universitas Islam Darul Ulum Lamongan, siti.amiroch@unisda.ac.id \\ ${ }^{3}$ Universitas Islam Darul Ulum Lamongan, syaifulp@ unisda.ac.id
}

\begin{abstract}
Graph theory can be applied in various fields of science such as transportation problems, communication networks, operations research, chemistry, cartography and so on. Graph theory does not only represent structure but in its application, a graph can also be colored. Many problems have graph coloring characteristics such as regional coloring. This regional coloring theory was applied to the map area of Sukodadi District which consists of 20 villages. In this area coloring uses the Greedy algorithm by first making a dual graph consisting of 20 vertices and 43 edges. Based on the results of regional coloring, the minimum number of colors is 4, namely red, blue, green and yellow, with each neighboring village having a different color.
\end{abstract}

Keywords: Graph Theory, Greedy Algorithm, Region Coloring

\begin{abstract}
Abstrak. Teori graf dapat diterapkan dalam berbagai bidang ilmu seperti masalah transportasi, jaringan komunikasi, riset operasi, ilmu kimia, kartografi dan lain sebagainya. Teori graf tidak hanya sekedar merepresentasikan struktur saja tetapi dalam aplikasinya suatu graf juga dapat diwarnai. Banyak persoalan yang mempunyai karakteristik pewarnaan graf seperti pewarnaan wilayah. Teori pewarnaan wilayah ini diaplikasikan pada wilayah peta Kecamatan Sukodadi yang terdiri atas 20 desa. Pada pewarnaan wilayah ini menggunakan algoritma Greedy dengan cara membuat graf dualnya terlebih dahulu yang terdiri dari 20 simpul dan 43 sisi. Berdasarkan hasil pewarnaan wilayah diperoleh jumlah warna minimum sebanyak 4 warna yaitu merah, biru, hijau dan kuning dengan setiap desa yang bertetangga memiliki warna yang berbeda.
\end{abstract}

Kata kunci : Teori Graf, Algoritma Greedy, Pewarnaan Wilayah

\section{Pendahuluan}

Teori graf merupakan salah satu studi terhadap bidang matematika yang diperkenalkan pertama kali oleh seorang ahli matematika asal Swiss, Leonhard Euler 1736. Teori graf merupakan pokok bahasan yang sudah tua usianya namun memiliki banyak terapan sampai saat ini dan merupakan topik yang banyak mendapat perhatian saat ini, karena model-model yang ada pada teori graf berguna untuk aplikasi yang luas. Secara kasar, graf adalah suatu diagram yang memuat informasi tertentu jika diinterpretasikan secara tepat. Tujuannya sebagai visualisasi objek-objek agar lebih mudah dimengerti [1]. Secara definisi, graf adalah suatu cabang matematika yang mempelajari hubugan himpunan tidak 
kosong yang memuat elemen-elemen yang disebut titik dan suatu daftar pasangan elemen itu yang disebut sisi [2].

Teori graf tidak hanya sekedar merepresentasikan struktur saja tetapi dalam aplikasinya suatu graf juga dapat diwarnai. Banyak persoalan yang mempunyai karakteristik seperti pewarnaan graf, sehingga menjadikan pewarnaan graf ini menarik untuk dipelajari lebih dalam. Masalah pewarnaan di dalam graf memiliki banyak variasi dengan tipe yang berbeda. Pewarnaan graf dibagi dalam tiga bagian, yaitu pewarnaan simpul (vertex coloring), pewarnaan sisi (edge coloring) dan pewarnaan wilayah (region coloring) [3]. Persoalan pewarnaan graf, tidak hanya sekedar mewarnai simpul-simpul atau sisi dengan warna berbeda dari warna simpul atau sisi tetangganya saja, namun juga menggunakan jumlah warna minimum yang disebut dengan bilangan kromatik pada graf.

Kecamatan sukodadi ini dipilih karena pada peta wilayah kecamatan sukodadi belum memiliki warna, sehingga daerah-daerah yang berbatasan langsung memiliki warna yang sama. Salah satu algoritma yang dapat digunakan untuk menentukan jumlah warna minimum pada pewarnaan peta kecamatan sukodadi adalah algoritma greedy. Algoritma greedy merupakan salah satu metode yang digunakan untuk memecahkan masalah optimasi dengan memanfaatkan strategi algoritmik yang dapat memecahkan masalah langkah demi langkah, yang setiap langkahnya mengambil pilihan terbaik pada saat itu dengan gagasan dasar adalah membangun solusi optimal di atas solusi lokal. Algoritma greedy dipilih dalam pewarnaan peta karena tidak membutuhkan waktu yang lama dalam menyelesaikan persoalan optimasi.

\section{Tinjauan Pustaka}

Pewarnaan graf adalah pemberian warna, yang biasanya direpresentasikan sebagai bilangan terurut mulai dari 1 atau dapat juga direpresentasikan langsung dengan menggunakan warna merah, biru, hijau dan lain-lain pada objek tertentu pada suatu graf. Objek tersebut dapat berupa simpul, sisi dan wilayah. Setiap simpul yang berdekatan atau bertetangga tidak mempunyai warna yang sama Terdapat persoalan di dalam pewarnaan graf, yaitu mewarnai graf tidak hanya sekedar mewarnai simpul-simpul dengan warna berbeda dari warna simpul tetangganya saja, namun dalam mewarnainya juga menginginkan jumlah macam warna yang digunakan sesedikit mungkin [4]. Pewarnaan pada graf dibedakan menjadi tiga yaitu, Pewarnaan Simpul (Vertex Coloring), Pewarnaan Sisi (Edge Coloring) dan Pewarnaan Wilayah (Region Coloring).

Pewarnaan simpul dari graf $G$ adalah sebuah proses pemberian warna-warna ke simpul-simpul suatu graf sedemikian sehingga tidak ada dua buah simpul yang bertetangga memiliki warna yang sama (Li et all, 2010). Graf $G$ berwarna $n$ jika terdapat sebuah pewarnaan dari $G$ yang menggunakan $n$ warna [3]. Pewarnaan simpul erat kaitannya dengan penentuan bilangan kromatik $X(G)$, yaitu jumlah minimal warna yang digunakan dalam mewarnai simpul [3].

Suatu pewarnaan sisi- $k$ untuk graf $G$ adalah suatu penggunaan sebagian atau semua $k$ warna untuk mewarnai semua sisi di $G$, sehingga setiap pasang sisi yang mempunyai simpul yang sama diberi warna yang berbeda [3].

Pewarnaan wilayah adalah warna yang diberikan ke setiap wilayah pada graf, sehingga tidak ada wilayah yang bersebelahan memiliki warna yang sama [3]. Pewarnaan wilayah ini diterapkan pada pewarnaan peta, dengan memberikan 
warna berbeda pada setiap wilayah yang saling bertetangga. Mewarnai wilayah pada suatu graf dapat menggunakan prinsip pewarnaan simpul pada graf [2].

Lebih lanjut, [2] menyebutkan beberapa prinsip yang harus diperhatikan dalam mewarnai peta yaitu:

1. Banyaknya warna yang harus digunakan harus seminimum mungkin.

2. Mewarnai wilayah pada peta berarti mewarnai simpul pada graf.

3. Dua buah simpul yang terhubung oleh satu atau lebih sisi tidak boleh diberi warna yang sama.

4. Mewarnai peta pakailah sebuah warna secara optimum, artinya warna baru digunakan setelah warna pertama tidak dapat digunakan lagi.

\section{Metode Penelitian}

Algoritma Greedy merupakan algoritma yang menghasilkan solusi melalui penyelesaian langkah perlangkah (step by step) dengan menerapkan 2 hal berikut pada tiap langkahnya [5]:

1. Pilihan yang diambil merupakan pilihan terbaik yang dapat diperoleh pada saat itu tanpa memperhatikan konsekuansinya kedepan nanti, hal ini bersesuaian dengan prinsip Algoritma Greedyyaitu "take what you canget now".

2. Berharap dengan memilih pilihan terbaik saat itu (optimum lokal) dapat mencapai solusi terbaik dari permasalahan yang dihadapi (optimum global).

Berdasarkan komponen algoritma greedy, untuk menemukan solusi optimal dari permasalahan pewarnaan peta ini digunakan rancangan algoritma greedyyang akan dipaparkan sebagai berikut [6].

1. Himpunan Kandidat C: himpunan kandidat dalam kasus pewarnaan peta ini merupakan himpunan kandidat seluruh jenis warna yang akan digunakan untuk mewarnai peta.

2. Himpunan Solusi S: himpunan solusi akan diisi dengan himpunan warna yang sudah digunakan untuk mewarnai peta.

3. Fungsi Seleksi: pada kasus ini fungsi seleksi terbagi menjadi 2, yaitu:

a. Fungsi seleksi simpul

Fungsi yang menyeleksi simpul mana yang harus dikerjakan terlebih dahulu. Prioritas pengerjaan dilihat dari simpul yang memiliki sisi terbanyak (derajat)

b. Fungsi seleksi warna

Fungsi ini akan memilih warna yang akan digunakan untuk mewarnai simpul pada peta. Penyeleksian warna ini akan dibagi menjadi 2 tahap, yaitu:

1) Jika layak warna akan diambil dari himpunan solusi, yaitu warna yang sudah dipakai sebelumnya.

2) Jika tidak satu pun warna dari himpunan solusi layak atau himpunan solusi masih kosong maka akan diambil warna dari himpunan kandidat, yaitu warna yang sama sekali belum digunakan.

4. Fungsi Kelayakan: fungsi yang akan memeriksa apakah suatu warna layak untuk digunakan pada sebuah simpul. Pemeriksaan kelayakan dapat 
dilakukan dengan melihat simpul-simpul yang bertetangga dengan simpul yang akan diwarnai.

5. Fungsi Obyektif: dalam kasus pewarnaan peta, fungsi obyektif adalah meminimalkan (minimasi) jumlah jenis warna yang digunakan pada proses pewarnaan seluruh simpul.

Cara kerja algoritma greedy dalam kasus pewarnaan peta akan dijabarkan sebagai berikut [6]:

1. Inisialisasi himpunan solusi dengan kosong.

2. Pemilihan simpul yang akan diisi warnanya dengan fungsi seleksi simpul.

3. Memilih kandidat warna menggunakan fungsi seleksi warna. Kurangi warna pada himpunan kandidat $C$, jika warna diambil dari himpunan kandidat $C$.

4. Periksa kelayakan warna yang dipilih menggunakan fungsi kelayakan. Warna yang layak digunakan untuk simpul terpilih akan dimasukkan ke dalam himpunan solusi, jika tidak layak maka proses kembali kelangkah 2.

5. Periksa apakah solusi sudah meliputi pewarnaan seluruh simpul dengan solusi optimal dengan fungsi obyektif. Proses pewarnaan akan berhenti jika pewarnaan telah mendapatkan solusi optimal, jika belum optimal kembali ke langkah 2.

Metodologi pewarnaan wilayah yang digunakan dalam penyelesaian pewarnaan wilayah kecamatan Sukodadi Lamongan ini sebagai berikut:

1. Merepresentasikan batas-batas wilayah setiap desa sebagai sisi dan perpotongan antar batas wilayah sebagai simpul.

2. Membuat graf dual dari peta kecamatan Sukodadi.

3. Merepresentasikan graf dual kedalam matriks ketetanggan yang menyatakan keterhubungan antar wilayah setiap Desa.

4. Menentukan derajat masing-masing simpul, yaitu menghitung jumlah batasbatas wilayah kecamatan yang saling bertetangga.

5. Mewarnai peta kecamatan menggunakan algoritma greedy.

6. Menentukan jumlah warna minimum yang diperoleh untuk mewarnai peta.

\section{Hasil dan Pembahasan}

Kecamatan Sukodadi berada di wilayah kabupaten Lamongan Provinsi Jawa Timur. Kecamatan ini memiliki luas wilayah 4.590,13 Ha. Kecamatan Sukodadi terdiri atas 20 desa. Dengan wilayah terluas adalah desa gedangan $\left(3,37 \mathrm{~km}^{2}\right)$. Desa tersebut berbatasan dengan desa sumberagung, desa banjarjo dan desa baturono. Gambar 1 merupakan gambar peta wilayah kecamtan sukodadi [1]. Setiap desa bertetangga dengan desa lain. Masing-masing ada yang bertetangga dengan dua desa, ada tiga desa dan paling banyakadalah yang bertetangga dengan 6 desa. 


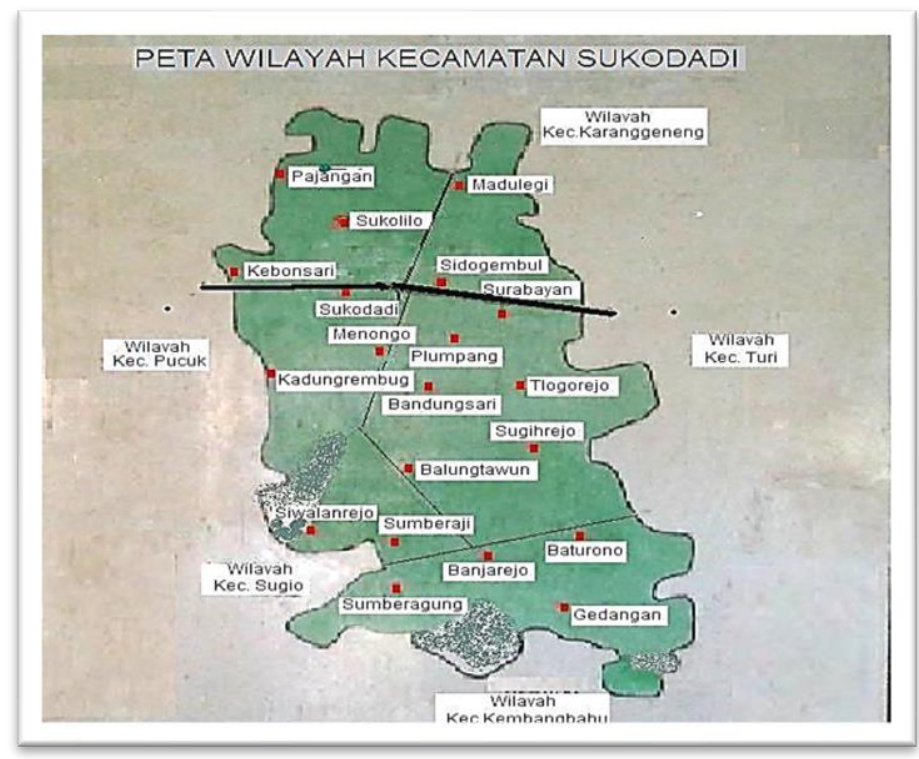

Gambar 1. Peta wilayah kecamatan sukodadi

Untuk mempresentasikan wilayah Kecamatan Sukodadi kedalam bentuk graf, langkah pertama adalah memberikan indeks masing-masing wilayah di Kecamatan Sukodadi diberi nama $r_{1}, r_{2}, r_{3}, \ldots, r_{20}$ ditunjukkan pada Tabel 1 berikut.

Tabel 1. Indeks Desa Kecamatan Sukodadi

\begin{tabular}{cl|cl}
\hline Indeks Desa & \multicolumn{1}{c|}{ Nama Desa } & Indeks Desa & Nama Desa \\
\hline$r_{1}$ & Siwalanrejo & $r_{11}$ & Bandungsari \\
$r_{2}$ & Sumberagung & $r_{12}$ & Plumpang \\
$r_{3}$ & Gedangan & $r_{13}$ & Tlogorejo \\
$r_{4}$ & Baturono & $r_{14}$ & Surabayan \\
$r_{5}$ & Banjarjo & $r_{15}$ & Sidogembul \\
$r_{6}$ & Sumberaji & $r_{16}$ & Sukodadi \\
$r_{7}$ & Kadung Rembug & $r_{17}$ & Kebonsari \\
$r_{8}$ & Menongo & $r_{18}$ & Sukolilo \\
$r_{9}$ & Balung Tawun & $r_{19}$ & Pajangan \\
$r_{10}$ & Sugihrejo & $r_{20}$ & Madulegi \\
\hline
\end{tabular}

Gambar 1 merepresentasikan wilayah Kecamatan Sukodadi kedalam suatu graf. Berdasarkan Gambar 1 kecamatan sukodadi merupakan graf bidang yang membagi ruang atau bidang kedalam daerah-daerah terhubung yang disebut dengan wilayah (region). Region terdiri dari simpul dan sisi yang menghubungkannya, maka Gambar 1 terdiri dari simpul dan sisi yang menghubungkannya yaitu:

$$
\begin{aligned}
& G=(V, E) \\
& V=\left\{v_{1}, v_{2}, v_{3}, v_{4}, v_{5}, \ldots v_{36}\right\} \\
& E=\left\{e_{1}, e_{2}, e_{3}, e_{4}, e_{5}, \ldots, e_{54}\right\}
\end{aligned}
$$




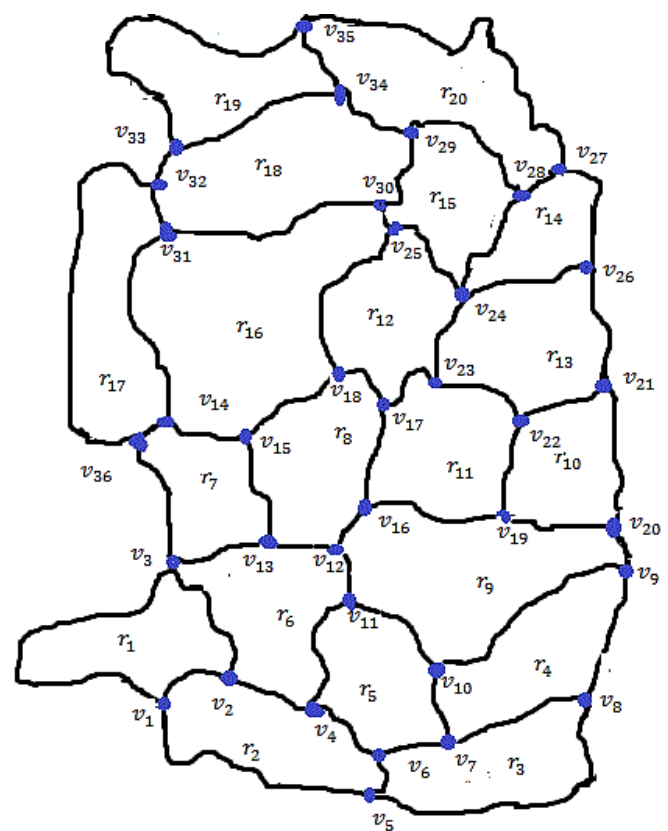

Gambar 1. Wilayah kecamatan terdiri dari 36 simpul dan 54 sisi

Selanjutnya, cara membuat graf dual dari peta Kecamatan Sukodadi adalah dengan merepresentasikan wilayah setiap desa sebagai simpul pada graf dengan notasi $V=\{1,2,3,4,5, \ldots, 20\}$ dan merepresentasikan wilayah setiap desa yang saling bertetangga sebagai sebuah sisi.

$G=(V, E)$

$V=\{1,2,3,4,5,6,7,8,9,10,11,12,13,14,15,16,17,18,19,20\}$

$E=\{(1,2),(1,6),(2,3),(2,5),(2,6),(3,4),(3,5),(4,5),(4,9),(5,6),(5,9),(6,7)$, $(6,8),(6,9),(7,8),(7,16),(7,17),(8,9),(8,11),(8,12),(8,16),(9,10),(9,11)$, $(10,11),(10,13),(11,12),(11,13),(12,13),(12,14),(12,15),(12,16),(13,14)$, $(14,15),(14,20),(15,16),(15,18),(15,20),(16,17),(16,18),(17,18),(18,19)$, $(18,20),(19,20)\}$

Graf dual peta Kecamatan Sukodadi ditunjukkan oleh Gambar 2 berikut.

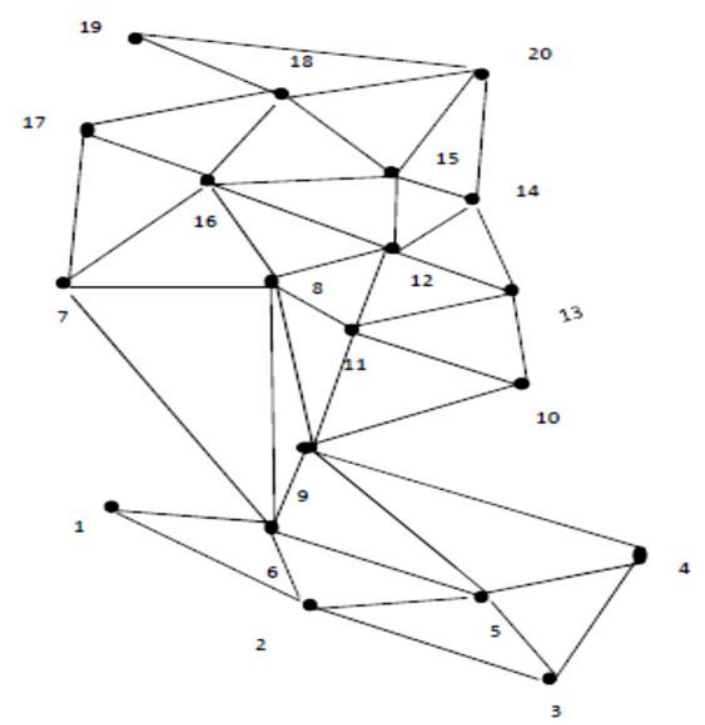

Gambar 2. Graf dual peta kecamatan sukodadi 
Matriks ketetanggaan merupakan suatu matriks yang dapat menyatakan keterhubungan antar simpul, yang mana pada kasus sebuah peta matriks ini berfungsi untuk mengetahui apakah wilayah satu dengan wilayah lainnya saling berhubungan. Matriks ketetanggaan peta Kecamatan Sukodadi yang terdiri dari 20 wilayah desa dapat direpresentasikan sebagai simpul dan dapat dibentuk ke dalam matriks 20 x 20 sebagai berikut:

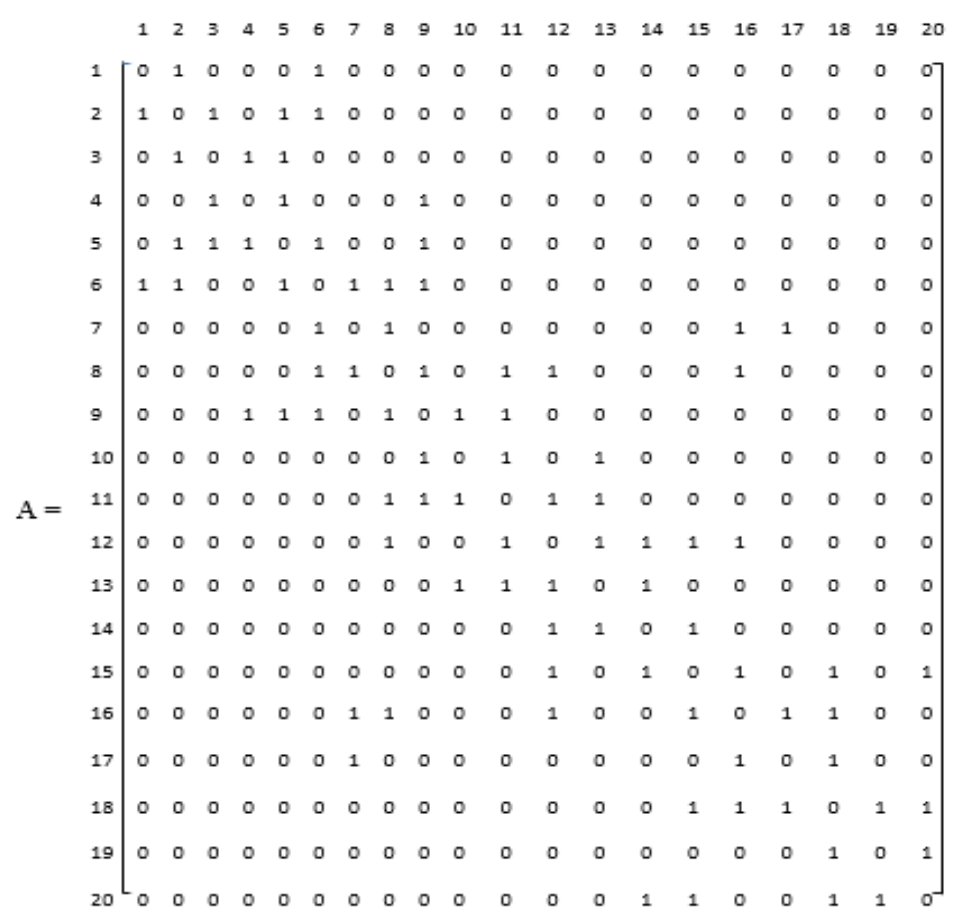

Derajat setiap wilayah yang direpresentasikan sebagai simpul dapat dihitung dengan cara menghitung berapa banyak sisi yang terhubung pada setiap simpul pada graf dualnya. Derajat setiap simpul dapat ditentukan dengan mudah dari matriks ketetanggannya, yaitu dengan menjumlahkan setiap baris atau kolom pada setiap simpul. Berdasarkan matriks ketetanggaan pada peta Kecamatan Sukodadi di atas dapat ditentukan derajat setiap simpulnya, dapat dilihat pada Tabel 2 berikut.

Tabel 2. Derajat simpul graf dual pada peta

\begin{tabular}{lcc|ccc}
\hline $\begin{array}{c}\text { Wilayah } \\
\text { Kecamatan }\end{array}$ & $\begin{array}{c}\text { Simpul } \\
\text { Graf }\end{array}$ & $\begin{array}{c}\text { Derajat } \\
\text { Simpul }\end{array}$ & $\begin{array}{c}\text { Wilayah } \\
\text { Kecamatan }\end{array}$ & $\begin{array}{c}\text { Simpul } \\
\text { Graf }\end{array}$ & $\begin{array}{c}\text { Derajat } \\
\text { Simpul }\end{array}$ \\
\hline Siwalanrejo & 1 & 2 & Bandungsari & 11 & 5 \\
Sumberagung & 2 & 4 & Plumpang & 12 & 6 \\
Gedangan & 3 & 3 & Tlogorejo & 13 & 4 \\
Baturono & 4 & 3 & Surabayan & 14 & 4 \\
Banjarjo & 5 & 5 & Sidogembul & 15 & 5 \\
Sumberaji & 6 & 6 & Sukodadi & 16 & 6 \\
Kadung Rembug & 7 & 4 & Kebonsari & 17 & 3 \\
Menongo & 8 & 6 & Sukolilo & 18 & 5 \\
Balung Tawun & 9 & 6 & Pajangan & 19 & 2 \\
Sugihrejo & 10 & 3 & Madu Legi & 20 & 4 \\
\hline
\end{tabular}


Berikut ini adalah tahap-tahap pewarnaan peta menggunakan Algoritma Greedy:

1. Membangun himpunan kandidat warna (misalkan ada 10 kandidat warna) $C=\{$ Merah, Biru, Hijau, Kuning, Ungu, Abu-abu, Coklat, Orange, Biru Muda, Merah Muda\}

2. Melakukan inisialisasi himpunan solusi $S$

Inisialisasi himpunan dengan kosong, karena pada tahap selanjutnya nanti himpunan solusi akan memuat elemen warna yang telah digunakan untuk mewarnai simpul. Himpunan $S=\{\}$.

3. Mengurutkan Simpul

Urutkan simpul dari yang mempunyai jumlah sisi terbanyak hingga yang paling sedikit.

Tabel 3. Urutan simpul peta berdasarkan jumlah derajat tertinggi

\begin{tabular}{cccccccccccccccccccccc}
\hline $\begin{array}{c}\text { Simpul } \\
\text { graf }\end{array}$ & 6 & 8 & 9 & 12 & 16 & 5 & 11 & 15 & 18 & 2 & 7 & 13 & 14 & 20 & 3 & 4 & 10 & 17 & 1 & 19 \\
\hline $\begin{array}{c}\text { Derajat } \\
\text { simpul }\end{array}$ & 6 & 6 & 6 & 6 & 6 & 5 & 5 & 5 & 5 & 4 & 4 & 4 & 4 & 4 & 3 & 3 & 3 & 3 & 2 & 2 \\
\hline
\end{tabular}

4. Fungsi Seleksi

a. Fungsi seleksi simpul

Berdasarkan Tabel 3 simpul yang memiliki derajat terbanyak adalah simpul 6, 8, 9, 12, 16 dengan derajat simpul adalah 6 dan dipilih simpul 6 .

b. Fungsi Seleksi Warna

1. Jika layak warna akan diambil dari himpunan solusi (warna yang sudah dipakai pada simpul sebelumnya)

2. Jika tidak satupun warna dari himpunan solusi layak atau himpunan solusi masih kosong, akan diambil warna dari himpunan kandidat $C$. untuk simpul 6 diambil dari himpunan kandidat $C$, dipilih warna merah yang merupakan kandidat warna pertama dari himpunan kandidat $C$.

5. Fungsi Kelayakan

Dapat dilihat dari gambar 2 bahwa simpul 6 bertetangga dengan 6 buah simpul yang belum diwarnai. Sehingga, warna merah ini otomatis dianggap layak digunakan untuk simpul 6.

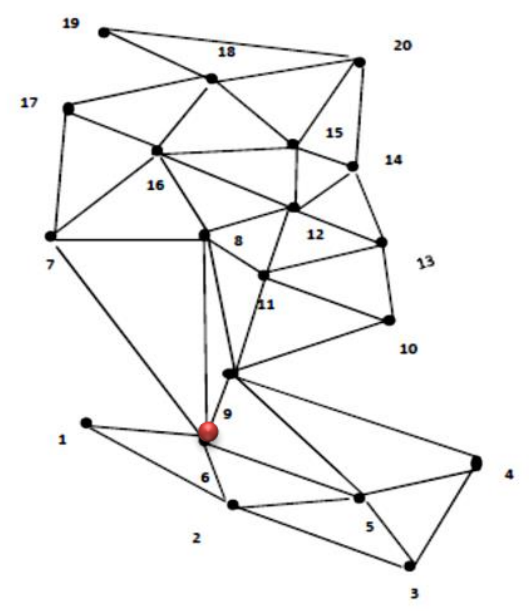

Gambar 3. Pewarnaan simpul 6 
6. Himpunan Solusi

Memasukkan warna merah yang digunakan untuk simpul 6 kedalam himpunan solusi:

$S=\{$ Merah $\}$

7. Fungsi Obyektif

Proses selanjutnya adalah memeriksa apakah solusi sudah meliputi pewarnaan seluruh simpul dengan solusi optimal, jika sudah maka berhenti dan jika belum kembali ke langkah seleksi simpul. Pewarnaan simpul pada tahap ini belum optimal karena simpul belum diwarnai semua (optimum local) sehingga solusi optimal belum didapat.

Maka selanjutnya akan kembali pada seleksi simpul hingga seluruh simpul telah diwarnai semua (optimum global) sehingga proses pewarnaan simpul pada peta Kecamatan Sukodadi selesai. Gambar 4 berikut merupakan hasil optimum global yang sudah tercapai.
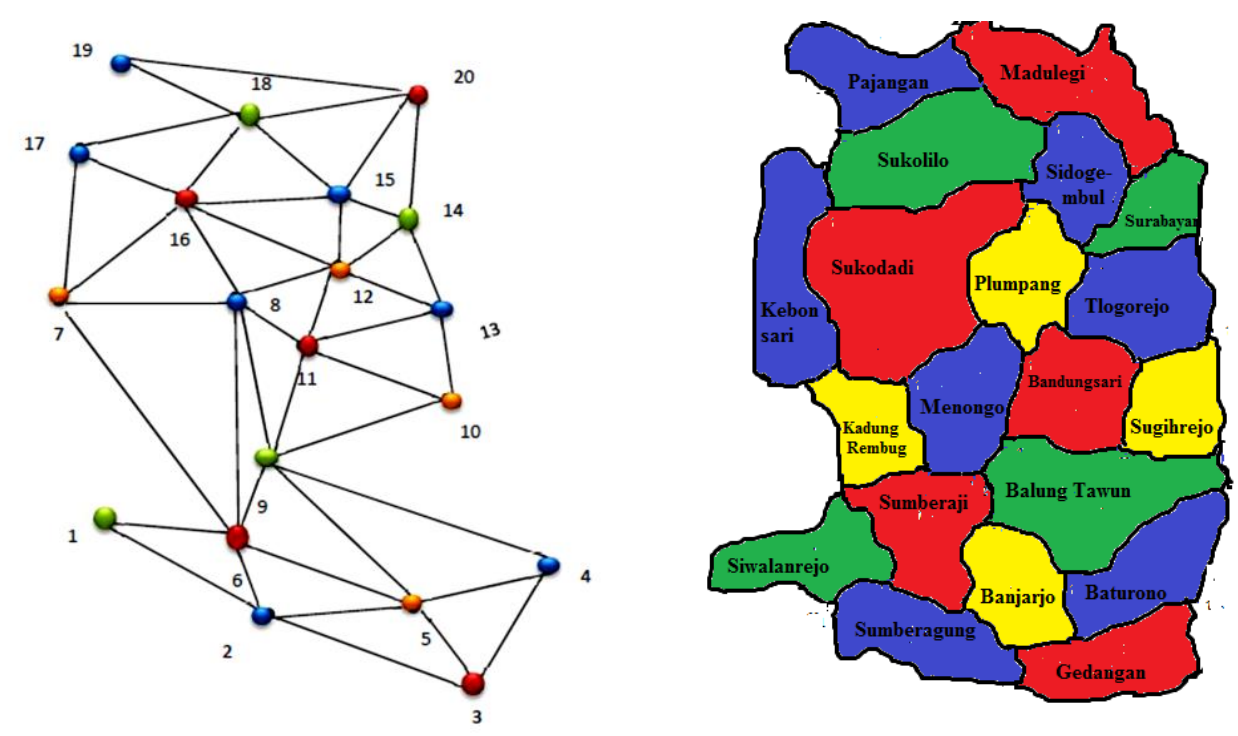

Gambar 4. Pewarnaan peta pada seluruh simpul (optimum global)

Jumlah warna minimum atau disebut dengan bilangan kromatik yangdiperoleh pada pewarnaan peta wilayah Kecamatan Sukodadi menggunakan algoritma Greedydapat dilihat dari berapa banyak anggota warna dalam himpunan solusi. Tujuan dari pewarnaan wilayah ini tercapai, karena solusi optimal (Optimum Global) yang didapatkan sesuai dengan yang diharapkan yaitu meminimumkan nilai solusi dalam hal ini warna yang digunakan hanya 4 warna dari 10 jenis warna yang disediakan.

\section{Simpulan}

Jumlah warna minimum (bilangan kromatik) pewarnaan wilayah pada peta Kecamatan Sukodadi diperoleh 4 warna, warna antar desa yang terhubung dengan satu sisi memiliki warna yang berbeda. 


\section{Daftar Pustaka}

[1] J. J. Siang, "Metematika Diskrit dan Aplikasinya padsa Ilmu Komputer," 2006.

[2] S. Wibisono, Matematika Diskrit. Jakarta: Graha Ilmu, 2004.

[3] J. L. Gross and J. Yellen, Graph theory and its applications. CRC press, 2005 .

[4] R. Munir, "Ilmu Komputer Matematika Diskrit," Ed. Ketiga. Inform. Bandung, 2005.

[5] H. S. Lubis, "Perbandingan Algoritma Greedy dan Dijkstra untuk menentukan lintasan terpendek," Dep. Mat. Univ. Sumatera Utara, Medan, 2009.

[6] M. Amrimirza, "Aplikasi Algoritma Greedy pada Pewarnaan Peta." Makalah IF2251 Strategi Algoritmik Institut Teknologi Bandung, 2007. 